\title{
ETANOL BRASILEIRO: PERSPECTIVAS E BARREIRAS NO MERCADO MUNDIAL.
}

\section{Janaina Lucena de Souza}

Graduada em Tecnologia em Comércio Exterior pelo Instituto Federal de Educação, Ciência e Tecnologia do Rio Grande do Norte. E-mail: janaina.lucena@gmail.com

Eduardo Janser de Araújo Dantas

Graduado em Engenharia Elétrica pela Universidade Federal do Rio Grande do Norte, graduado em Ciências Econômicas pela Universidade Federal do Rio Grande do Norte e mestrado em Engenharia Elétrica pela Universidade Federal do Rio Grande do Norte.

E-mail: eduardojanser@yahoo.com.br.

\section{RESUMO}

A mudança da matriz energética mundial é inevitável para que o mundo não chegue a um colapso energético e ambiental. Nesse contexto o etanol surge como principal alternativa capaz de substituir os combustíveis de origem fóssil e o Brasil, por seu pioneirismo na produção desse biocombustível, tem a chance liderar o mercado agroenergético mundial. Porém, para a formação de um mercado mundial de etanol, o Brasil ainda tem que superar a resistência de alguns países ao uso do álcool combustível, e as barreiras comerciais impostas à sua importação. Utilizando um estudo descritivo-explicativo, por meio de pesquisa bibliográfica e documental, esse trabalho teve como objetivo diagnosticar as perspectivas dos comércios nacional e internacional de etanol, identificando seus principais mercados, oportunidades e quais as principais barreiras políticas e econômicas mundiais impostas à utilização da biomassa, em especial do etanol, como substituto dos combustíveis fósseis.

Palavras-Chave: Matriz Energética. Etanol. Mercado Agroenergético Mundial. Barreiras Comerciais.

\section{BRAZILIAN ETANOL: PERSPECTIVES AND BARRIERS IN THE WORLD MARKET.}

\begin{abstract}
A change in the global energetic matrix is inevitable for the world do not come to an energy and environmental collapse. In this context, the main alternative that is able to replace the fossil fuels is the ethanol, and Brazil, for its pioneering work in the production of this biofuel, has the chance to leader the global agrienergetic market. But to form a world market for ethanol, Brazil has yet to overcome the resistance of some countries to use alcohol fuel, and trade barriers imposed on its importation. Using a descriptive-explanatory study, through literature and documentation search, this work had as objective to diagnostic the prospects of national and international ethanol trade, identifying its main markets, opportunities and which are the main global political and economic barriers imposed to the use of biomass, especially to ethanol, as a substitute for fossil fuels.
\end{abstract}

Key Words: Energetic Matrix. Ethanol. Global Agroenergetic Market. Trade Barriers. 


\section{ETANOL BRASILEIRO: PERSPECTIVAS E BARREIRAS NO MERCADO MUNDIAL.}

\section{INTRODUÇÃO}

Os países e blocos econômicos vivem, na atualidade, uma fase de grande complexidade em relação ao suprimento de energia, tendo em vista o previsto fim dos combustíveis fósseis, que sustentou a evolução do mundo nos últimos duzentos anos e a degradação ambiental provocada por esses combustíveis.

Diante desses problemas, a substituição das fontes de energia utilizadas atualmente é inevitável, tornando-se apenas uma questão de tempo, haja vista a importância que a energia tem no crescimento e no desenvolvimento econômicos de uma nação e os impactos negativos que as atuais fontes de energia têm causado sobre o meio ambiente.

Por isso, o mundo hoje busca formas de energia extensivas, permanentes e limpas que evitem um colapso energético, e ao mesmo tempo não causem tantos danos ao meio ambiente como as tradicionais fontes de energia têm causado ao longo do tempo, a exemplo da emissão de gases poluentes pela queima dos derivados de petróleo. Dentro desse cenário, os biocombustíveis (combustíveis extraídos a partir da biomassa), em especial o etanol, surgem como a principal alternativa para a substituição dos combustíveis fósseis.

Nesse contexto, o Brasil vem se destacando no mercado mundial por seu pioneirismo e experiência na produção do álcool combustível, que o colocam à frente na corrida pela busca de um sistema energético renovável e auto-sustentado.

$\mathrm{E}$ as perspectivas mundiais em relação ao aumento da demanda do etanol como combustível são positivas. Diversos países estão aceitando a sua utilização, e aqueles que já o faziam vêm incentivando um maior consumo do mesmo.

Porém, ainda não existe um mercado internacional de etanol consolidado. O interesse, principalmente brasileiro, em transformar o etanol no combustível do futuro esbarra na resistência de alguns países, que ainda insistem em manter o petróleo e seus derivados como sua principal fonte de energia, e nas barreiras comerciais utilizadas pelos demais produtores de etanol que, por não possuírem vantagens comparativas na produção do mesmo, oferecem significativos subsídios aos seus produtores e impõem freqüentemente sobretaxas ao etanol importado sob o argumento de proteger sua produção interna.

Por isso, diante do imenso potencial brasileiro e da possibilidade do país de se tornar líder na produção mundial de energia a partir da biomassa, esse trabalho teve como objetivo diagnosticar as perspectivas dos comércios nacional e internacional de etanol, identificando seus principais mercados, oportunidades e quais as principais barreiras políticas e econômicas mundiais impostas à utilização da biomassa, em especial do etanol, como principal fonte de energia, com a finalidade de oferecer aos meios acadêmico e empresarial, um maior detalhamento do assunto, de maneira a colaborar com a ascensão do país à liderança mundial no setor da agroenergia. 


\section{MUDANÇAS NA MATRIZ ENERGÉTICA MUNDIAL}

A modernização vivida pelo Ocidente desde a Primeira Revolução Industrial até os dias de hoje, fez com que sua sociedade saísse da vida rural para a urbana, alterando seus costumes e cotidiano. $\mathrm{O}$ que antes o homem conseguia por meio da energia gerada pelo trabalho manual, ele passou a obter com equipamentos movidos à energia proveniente dos mais diversos recursos naturais.

Assim, como afirmam Hinrichs e Kleinbach (2003), a energia tornou-se um dos principais constituintes da idade moderna, estando presente em todos os setores da sociedade economia, ambiente, relações internacionais - e na vida das pessoas - transporte, alimentação, moradia.

No entanto, com o aumento da população mundial, suprir a necessidade energética que a sociedade demanda tornou-se algo preocupante. Tanto para os países desenvolvidos, quanto para os países em desenvolvimento, a energia é um elemento fundamental para o desenvolvimento e o crescimento econômicos, uma vez que ela é necessária para a fabricação de bens e para o fornecimento de diversos serviços.

Hoje dois grandes problemas têm sido alvo de preocupação da comunidade internacional em relação ao fornecimento e o consumo de energia: o esgotamento dos recursos energéticos e a degradação ambiental que o uso de combustíveis fósseis como principal fonte de energia, desde o século XVIII, vem provocando.

\section{O ESGOTAMENTO DOS RECURSOS ENERGÉTICOS}

Desde o início da industrialização todos os recursos que o homem utilizou para a obtenção de energia provêm de fontes não-renováveis. No início da Revolução Industrial, os recursos energéticos explorados eram a madeira e o carvão mineral. Ao longo do tempo, com o aumento do consumo de energia, a humanidade buscou outras fontes para suprir sua necessidade energética como, por exemplo, o vento (energia eólica), o calor do sol (energia solar) e a força das águas (energia hidrelétrica). Contudo, apesar dessas novas técnicas de obtenção de energia, ainda são os combustíveis fósseis os mais utilizados para a geração de energia, destacando-se o carvão, o gás natural e o petróleo.

\section{O CARVÃO}

Até a Segunda Guerra Mundial, o carvão era o principal combustível para a geração de energia no mundo. Com a descoberta de combustíveis derivados do petróleo e da energia nuclear, sua atuação na produção energética global passou a ser de coadjuvante.

"Em termos de participação na matriz energética mundial, segundo o Balanço Energético Nacional (2003), o carvão é atualmente responsável por cerca de 7,9\% de todo o consumo mundial de energia e de 39,1\% de toda a energia elétrica gerada" (AGÊNCIA NACIONAL DE ENERGIA ELÉTRICA, 2007). 
Mesmo com os graves impactos ambientais que provoca, o carvão ainda é uma importante fonte de energia a nível global. Como mostra a ANEEL, as principais razões para isso são: abundância e distribuição geográfica das reservas, e o baixo custo e estabilidade nos preços, quando comparado a outros combustíveis.

No entanto, o principal prejuízo apresentado pelo carvão mineral são os impactos ambientais, causados não apenas por sua queima, mas também por sua extração. Esta última afeta principalmente os recursos hídricos, o solo e o relevo das áreas vizinhas às minas, uma vez que a abertura de poços de acesso ao trabalho provoca a emissão de óxido de enxofre, óxido de nitrogênio, monóxido de carbono, entre outros poluentes. Além disso, durante a drenagem das minas, águas sulfurosas são lançadas no ambiente externo, provocando a elevação das concentrações de sulfatos e de ferro e a redução de $\mathrm{pH}$ no local de drenagem.

Já a sua queima emite grandes quantidades de material particulado ${ }^{1}$ e gases poluentes. Entre os gases, os que se destacam são o dióxido de enxofre e os óxidos de nitrogênio, que além de prejudicar a saúde humana, são os principais responsáveis pela formação da chuva ácida.

\section{O GÁS NATURAL}

O uso do gás natural para a geração de energia é o que apresenta as maiores vantagens quando comparado ao uso de outros combustíveis fósseis. É mais barato, causa um baixo impacto ambiental por possuir uma queima mais limpa, tem alta disponibilidade, apresenta facilidade no transporte e no manuseio é mais seguro.

Porém como todo combustível fóssil, sua principal desvantagem é o fato de não ser renovável. Como mostram Hinrichs e Kleinbach (2003), as reservas mundiais de gás natural são estimadas em mais de 5.000 trilhões de pés cúbicos, o que é suficiente para abastecer a demanda mundial durante 60 anos, se as taxas de consumo atuais forem mantidas.

\section{O PETRÓLEO}

Desde o início da exploração dos campos e perfuração dos poços de petróleo, o "ouro negro", como foi chamado, teve papel fundamental no desenvolvimento da economia internacional. Sua importância atingiu o auge durante a década de 1970, quando chegou a representar cerca de $50 \%$ do consumo mundial de energia primária ${ }^{2}$, declinando com o passar do tempo. Mesmo assim, de acordo com a Agência Internacional de Energia (2003), ainda é o recurso energético de maior expressividade, representando aproximadamente $43 \%$ do consumo mundial da mesma energia. ${ }^{2}$

\footnotetext{
${ }^{1}$ Material particulado é constituído de pós e cinzas em suspensão nos gases emitidos durante a queima de combustíveis fósseis.

${ }^{2}$ Energia primária é a energia como encontrada na natureza. Pode ser de origem fóssil, renovável ou nuclear, sendo transformada em um combustível utilizável ou eletricidade para que possa ser consumida.
} 
Embora apresente diversas possibilidades de aplicação, o petróleo causa grandes infortúnios à economia internacional e à sociedade. Os problemas começam pela distribuição geográfica das reservas petrolíferas, que são irregulares quando comparadas aos principais centros de consumo. Como mostra a ANEEL, 2007, cerca de 2/3 das reservas provadas estão localizados no Oriente Médio, que responde por, aproximadamente, $6 \%$ do consumo mundial. Por outro lado, a América do Norte, que possui apenas $4,8 \%$ das reservas, é responsável por cerca de $30 \%$ desse consumo.

Essa irregularidade na distribuição das reservas facilitou a formação de um mercado oligopolista em torno do petróleo, e propiciou a formação do mais poderoso cartel do mundo, a Organização dos Países Exportadores de Petróleo (OPEP).

Outro ponto que inquieta a economia mundial são as previsões para o fim do petróleo. Estudos mais pessimistas afirmam que, se a produção permanecer no mesmo nível de cada ano anterior, mantendo-se as mesmas taxas de consumo, as reservas atuais comprovadas, durariam aproximadamente 40 anos.

Além das questões econômicas, o petróleo também provoca graves impactos ambientais. É a ele atribuída a maior parte da responsabilidade pelo aquecimento global, pois, dentre os principais gases poluentes emitidos pela queima de seus derivados, destacam-se o dióxido de carbono $\left(\mathrm{CO}_{2}\right)$, o dióxido de enxofre $\left(\mathrm{SO}_{2}\right)$ e o material particulado. Esses poluentes afetam o meio ambiente, causando conseqüências locais e globais, além de provocarem diversos males à saúde humana, como distúrbios respiratórios, alergias, lesões degenerativas no sistema nervoso e em órgãos vitais, câncer, entre outros.

\section{A DEGRADAÇÃO AMBIENTAL}

Como se pôde observar com a análise dos combustíveis fósseis atualmente utilizados, nenhum deles tem impacto nulo sobre o meio ambiente. Mesmo aqueles considerados menos ofensivos, como o gás natural, causam danos ambientais, na maioria das vezes irreversíveis. Isso fez com que a substituição dos combustíveis fósseis deixasse de ser uma questão puramente econômica, tornando-se também uma questão ambiental.

\section{O AQUECIMENTO GLOBAL}

A superfície e a atmosfera da Terra são mantidas aquecidas principalmente pela energia proveniente do Sol. Da luz incidente total que chega à Terra, cerca de $50 \%$ alcança a superfície onde é absorvida. Outros $20 \%$ da luz incidente são absorvidos por gases e pelas gotículas de água presentes no ar; os 30\% restantes são refletidos de volta ao espaço pelas nuvens, gelo, neve, areia, e por outros corpos refletores, sem que ocorra qualquer absorção (BAIRD, 2002).

Segundo Baird, 2002, essa luz incidente pode ser dividida em duas partes: a visível, que possui limites entre a luz violeta e a vermelha; e a não visível, que está no infravermelho (IR). De toda a energia recebida do Sol, pouco mais da metade é IR, e o restante é luz visível. 
Em condições normais, a terra reflete a radiação recebida do sol, em forma de calor, para o espaço, liberando a mesma quantidade de energia que recebe do Sol, mantendo, assim, a sua temperatura constante. Essa energia emitida não se encontra na região visível da luz, mas sim na região do infravermelho, chamada de infravermelho térmico (BAIRD, 2002).

Entretanto, alguns gases presentes no ar podem absorver temporariamente a luz infravermelha térmica de comprimentos de onda específicos, fazendo com que nem todo o IR emitido pela superfície e pela atmosfera terrestres escape diretamente para o espaço. Logo após sua absorção por moléculas presentes no ar, como o $\mathrm{CO}_{2}$, a luz infravermelha é reemitida em todas as direções, de modo completamente aleatório. Desta maneira, uma parte do IR térmico é direcionada de volta à superfície, sendo reabsorvido, e conseqüentemente provocando o aquecimento adicional tanto da superfície como do ar (BAIRD, 2002).

A esse fenômeno dá-se o nome de efeito estufa, e, de acordo com Baird, 2002, é ele o responsável pelo fato de a temperatura média da Terra ser de aproximadamente $+15^{\circ} \mathrm{C}$, e não $-15^{\circ} \mathrm{C}$, temperatura que predominaria se gases que absorvem o IR não estivessem presentes na atmosfera.

Ao contrário do que muitos pensam, o efeito estufa não é provocado pela poluição, mas se trata de um mecanismo natural do planeta para se manter aquecido, evitando que sua superfície seja coberta por uma espessa camada de gelo. Segundo Baird, 2002, o fenômeno que preocupa os cientistas é o aumento da concentração dos gases que absorvem a luz infravermelha térmica, que resultaria no redirecionamento de uma maior quantidade de energia, o que poderia aumentar a temperatura média da Terra além dos $15^{\circ} \mathrm{C}$.

\section{OS PRINCIPAIS GASES INDUTORES DO EFEITO ESTUFA}

O aumento da concentração de substâncias poluentes no ar não é um fato recente. Estudos feitos com amostras de ar aprisionado em blocos de gelo na Antártida indicam que a concentração atmosférica de gás carbônico cresceu cerca de $30 \%$ desde a época préindustrial (antes de 1750) até 1998 (BAIRD, 2002).

Dentre os principais gases poluentes, podem ser citados o dióxido de carbono, o monóxido de carbono $(\mathrm{CO})$, e o óxido nitroso $\left(\mathrm{N}_{2} \mathrm{O}\right)$. O dióxido de carbono (ou gás carbônico) é o gás indutor de efeito estufa de maior importância, respondendo por $76 \%$ do total de emissões relacionadas ao aquecimento global, e grande parte do aumento da sua concentração no ar deve-se à queima de combustíveis fósseis, principalmente carvão, petróleo e gás natural (BAIRD, 2002).

O exemplo mais conhecido dos efeitos que esses gases provocam na atmosfera é o smog (termo originado da combinação das palavras smoke - fumaça e fog - neblina): uma neblina amarela-amarronzada, com odor desagradável, que afeta a saúde humana e pode provocar danos nas plantas e nos animais.

De acordo com as projeções feitas pelo Painel Intergovernamental sobre as Mudanças do Clima - IPCC (sigla em inglês de Intergovernmental Panel on Climate Change), se nenhuma providência for tomada para diminuir a emissão de $\mathrm{CO}_{2}$ e de outros gases 
poluentes, em, aproximadamente, 2035 a temperatura média do ar será $1^{\circ} \mathrm{C}$ mais alta que em 1990. Já no ano de 2100 ela aumentará mais $2^{\circ} \mathrm{C}$.

Esse aumento de $3^{\circ} \mathrm{C}$ pode parecer pequeno, porém, segundo Baird, 2002, a temperatura média do ar atualmente é quase $6^{\circ} \mathrm{C}$ mais quente que nos períodos mais frios das eras glaciais. Além disso, com a Terra ficando $3^{\circ} \mathrm{C}$ mais quente existe a previsão para um aumento na quantidade total de chuvas globais, tendo em vista que as precipitações aumentam em média $2 \%$ para cada grau Celsius a mais na temperatura. Sendo assim, o mundo se tornará mais úmido, porém as áreas hoje atingidas pela seca ficarão ainda mais secas. Somado a isso calcula-se um aumento de aproximadamente meio metro no nível dos mares e oceanos perto de 2100 (além dos $10-25 \mathrm{~cm}$ já registrados nos últimos cem anos).

Diante dos danos já causados pelo aquecimento global, e daqueles que ainda podem ocorrer, a população mundial cobra de seus governantes soluções que possam amenizar, ou até reverter os danos provocados na natureza ao longo de tantos anos de poluição. Com esse objetivo, os líderes de diversos países discutem, desde o final da década de 1980, medidas que possam diminuir a emissão de gases poluentes, sem, contudo, afetar seu crescimento econômico.

\section{O PROTOCOLO DE KYOTO}

As discussões a respeito do desenvolvimento sustentável tiveram seu início em outubro de 1988, quando foi realizada na cidade de Toronto, Canadá, a Toronto Conference on the Changing Atmosphere. Esse foi o primeiro grande encontro entre autoridades e cientistas para tentar solucionar o problema da poluição. Em seguida, foi realizado na cidade de Sundsvall, Suécia, o IPCC's First Assessment Report, em agosto de 1990, que resultou, dois anos depois, na Convenção-Quadro das Nações Unidas sobre a Mudança Climática, realizada na cidade do Rio de Janeiro.

Todos esses eventos culminaram na $3^{\text {a }}$ Conferência das Partes da Convenção das Nações Unidas sobre Mudanças Climáticas, em dezembro de 1997 no Japão. A Conferência reuniu representantes de 166 países para discutir providências necessárias para combater o aquecimento global. Como resultado do encontro, foi elaborado o Protocolo de Kyoto, estabelecendo a redução das emissões totais de seis gases de efeito estufa (entre eles o dióxido de carbono) por parte dos países desenvolvidos e com economia em transição (conhecidos pela Convenção como "Países do Anexo 1"). O documento estabelece uma meta de 5,2\% na redução da emissão de poluentes no período entre 2008 e 2012, tendo como parâmetro os níveis de 1990.

Desde sua criação, o Protocolo encontrou dificuldades para ser aceito e ratificado. Para tornar-se um regulamento internacional, o documento precisava ser assinado por um grupo de países que respondessem por, no mínimo, 55\% da emissão de gases poluentes na atmosfera. Porém, em 2001, os Estados Unidos (maior poluidor mundial) desistiram do acordo, e mesmo com a adesão de 127 países, a soma de emissões era de apenas $44 \%$ (Entenda o Protocolo de Kyoto - Revista Época, 2005). Só em 2004, com a entrada da Rússia (segundo maior poluidor mundial), foi alcançado o índice necessário para a implementação do documento, que entrou em vigor em 16 de janeiro de 2005. 
De acordo com o Ministério do Meio Ambiente, apud Milaré (2005, p.1030) o Protocolo para os Estados-partes dita as seguintes diretrizes e obrigações:

I. O Protocolo orienta as partes para que promovam: o aumento da eficiência energética; a proteção de sumidouros e reservatórios; as formas sustentáveis de agricultura e de energia; e as políticas fiscais que tenham por fim a redução das emissões de gases de efeito estufa. As partes devem formular programas nacionais para os setores de transporte, energia, agricultura, etc., com vistas a diminuir o nível de emissões, além de cooperarem para o desenvolvimento e a difusão de tecnologias ambientalmente seguras.

II. As partes incluídas no Anexo I da Convenção devem assegurar que suas emissões agregadas sejam reduzidas, pelo menos, em percentual de 5\% abaixo dos níveis de 1990, entre os anos de 2008 e 2012 - primeiro período de compromisso.

III. As partes do Anexo I se comprometem a criar um sistema nacional para estimativa das emissões antrópicas por fontes e das remoções por sumidouros de todos os gases de efeito estufa. A metodologia para a contabilidade deve ser reconhecida pelo IPCC e acordada entre as Partes.

IV. Qualquer Parte pode transferir ou adquirir de qualquer outra Parte unidades de redução de emissões resultantes de projetos que se caracterizem por esse escopo e contemplem sumidouros de gases de efeito estufa, em qualquer setor da economia.

Ainda sobre as diretrizes e obrigações dos Estados-partes, o Ministério da Ciência e Tecnologia, apud Milaré (2005, p.1030) observa que:

I. Fica estabelecido o Mecanismo de Desenvolvimento Limpo - MDL. As partes não incluídas no Anexo I beneficiar-se-ão de atividades de projetos que resultem em reduções certificadas de emissões; e aquelas incluídas no Anexo I podem utilizar as reduções certificadas de emissões, resultantes de tais atividades de projetos, para contribuir com o cumprimento parcial de seus compromissos.

Fruto de uma proposta brasileira, o principal objetivo do Mecanismo de Desenvolvimento Limpo é assistir as Partes do Não Anexo 1 da Convenção mediante fornecimento de capital para financiamento de projetos que visem a redução de gases do efeito estufa. Assim, países desenvolvidos que não atinjam suas metas, podem financiar projetos em países em desenvolvimento como forma de cumprir parte dos seu compromissos.

Com isso, o Protocolo estimula os países a cooperarem ente si por meio de duas linhas de ação:

- Reformar os setores de energia e transportes; promover o uso de fontes energéticas renováveis, eliminando ou reduzindo drasticamente o uso de combustíveis fósseis; eliminar mecanismos financeiros e de mercado inapropriados aos fins da Convenção; limitar as emissões de metano no gerenciamento de resíduos e dos sistemas energéticos, e;

- Proteger florestas; promover o seqüestro de carbono por meio de sumidouros e da estocagem dos gases de efeito estufa retirados da atmosfera, como por exemplo, a injeção de $\mathrm{CO}_{2}$ em reservatórios geológicos.

Com todas essas medidas exigidas pelo Protocolo, se o mesmo for implementado com sucesso, calcula-se que a temperatura da Terra diminua entre $1,4^{\circ} \mathrm{C}$ e $5,8^{\circ} \mathrm{C}$ até 2100 . 


\section{BIOMASSA COMO ALTERNATIVA}

Promover segurança energética, diminuir a poluição do ar provocada pelos veículos e diminuir, ou mesmo eliminar, a emissão de gases indutores do efeito estufa são os principais objetivos que conduzem os Governos a identificar e comercializar alternativas aos combustíveis fósseis. Por isso, diversas fontes renováveis de energia vêm sendo exploradas como alternativas sustentáveis e de longo prazo às fontes tradicionais. Nessa busca por uma fonte de energia que substitua plenamente os combustíveis de origem fóssil, a biomassa vem se destacando como principal alternativa.

A biomassa nada mais é que material orgânico, como madeira, grãos, dejeto agrícola, e vegetação, que geram energia por meio de sua combustão direta ou da queima de combustíveis biodegradáveis produzidos a partir dela, conhecidos como biocombustíveis.

Mais que uma alternativa, a biomassa constitui a base para o desenvolvimento de um modelo energético autônomo e auto sustentado, devido a sua natureza renovável e espacialmente dispersa, uma vez que, como mostra Alves Filho, 2003, depende, basicamente, de farta radiação solar, água abundante e ampla disponibilidade de terras agricultáveis para sua produção.

Além disso, é a única forma de energia capaz de substituir o petróleo, uma vez que seus derivados estão aptos a ocupar o lugar dele sob forma líquida, gasosa e sólida, em proporções compatíveis com o consumo mundial, atual e futuro (ALVES FILHO, 2003).

O fato de ser uma fonte de energia com possibilidade de produção em quase todo o território mundial, proporcionando maior estabilidade no fornecimento de combustíveis, é apenas uma das vantagens na utilização da energia de biomassa, entre tantas outras. $\mathrm{O}$ Departamento de Engenharia Elétrica da Universidade Estadual de São Paulo - UNESP em portal eletrônico sobre biomassa, cita alguns exemplos:

a) Baixo custo de aquisição;

b) Não emissão de dióxido de enxofre;

c) Suas cinzas são menos agressivas ao meio ambiente que as provenientes de combustíveis fósseis;

d) Menor corrosão dos equipamentos (caldeiras, fornos);

e) Menor risco ambiental;

f) Suas emissões não contribuem para o efeito estufa; e,

g) Geração de empregos, uma vez que plantas de pequeno porte também podem ser utilizadas para sua aquisição.

Em função dessas vantagens, e para atingir os objetivos estabelecidos pelo Protocolo de Kyoto, vários países estão substituindo o uso de combustíveis fósseis, principalmente no 
setor de transportes, por biocombustíveis, sendo os mais utilizados e conhecidos atualmente o biodiesel e o etanol.

\section{BIODIESEL}

É um biocombustível que pode ser produzido a partir de gorduras animais ou de óleos vegetais de dezenas de espécies, tais como mamona, dendê (palma), girassol, babaçu, amendoim, pinhão manso e soja, dentre outras (PORTAL DO BIODIESEL, 2008).

O biodiesel só pode ser utilizado em motores movidos a diesel, sejam eles automotivos ou estacionários (ex.: geradores de eletricidade), podendo ser usado puro ou misturado com o óleo diesel de petróleo em qualquer proporção.

Como mostra o Portal BiodieselBR, 2008, para identificar a concentração de biodiesel em uma mistura com óleo diesel de petróleo, foi adotada uma nomenclatura mundial, a BXX. Nela, XX é a porcentagem de biodiesel na mistura como, por exemplo, B2, B5, B20 e B100, que são combustíveis com concentração de 2\%, 5\%, 20\% e 100\% de biodiesel na mistura, respectivamente.

Ainda segundo o BiodieselBR, a experiência de utilização do biodiesel no mercado de combustíveis tem se dado em quatro níveis de concentração: puro (B100), misturas (B20 a B30), aditivo (B5) e aditivo de lubricidade (B2); sendo as misturas em proporções volumétricas entre $5 \%$ e $20 \%$ as mais usuais.

Dentre as principais vantagens na utilização do biodiesel, pode-se citar (PORTAL BIODIESELBR, 2008):

a) É uma fonte renovável de energia;

b) É um ótimo lubrificante e pode aumentar a vida útil do motor;

c) Tem baixo risco de explosão, necessitando de uma fonte de calor acima de 150 graus Celsius para explodir;

d) Tem fácil transporte e armazenamento devido ao baixo risco de explosão;

e) Seu uso como combustível proporciona ganho ambiental para todo o planeta, pois colabora para diminuir a poluição e o efeito estufa;

f) Para sua utilização, não é necessária nenhuma adaptação em caminhões, tratores ou máquinas;

g) Substitui o diesel sem necessidade de ajustes nos motores;

h) Os óleos vegetais usados na produção do biodiesel podem ser obtidos de qualquer oleaginosa;

i) Na formação das sementes oleaginosas o gás carbônico é absorvido pela planta; 
j) O calor produzido por litro é quase igual ao do diesel;

k) Pouca emissão de partículas de carvão;

1) É constituído de carbono neutro. As plantas capturam todo o $\mathrm{CO} 2$ emitido pela queima do biodiesel e separam o CO2 em Carbono e Oxigênio, neutralizando suas emissões;

m) Contribui para a geração de empregos no setor primário, mantendo o trabalhador no campo, reduzindo, assim, o inchaço populacional nas grandes cidades.

\section{ETANOL}

O álcool etílico, ou etanol, é um álcool obtido por meio da fermentação de açúcares, comumente usado em bebidas alcoólicas ou como combustível, que pode ser produzido a partir de várias matérias primas como milho, trigo, beterraba e cana-de-açúcar.

Assim como o biodiesel substitui o óleo diesel de petróleo, o etanol substitui a gasolina, podendo ser usado puro ou misturado com a mesma, em porcentagens variadas. No Brasil existem dois tipos de etanol: o hidratado, com 5\% de água que abastece automóveis com motores a álcool e bicombustíveis, e o anidro, com 0,5\% de água que é misturado à gasolina em uma proporção de $20 \%$ a $25 \%$ (PORTAL ETANOL VERDE - CARTILHA DO ETANOL, 2008).

Do ponto de vista sócio-ambiental, sua utilização como combustível tem-se mostrado como a principal alternativa para diminuir a emissão de gases de efeito estufa na atmosfera, uma vez que a molécula do etanol possui um átomo de oxigênio, tornando sua combustão mais completa e com menores emissões de óxido de carbono (CO). Dentre as vantagens sócio-ambientais do etanol, podem ser citadas também:

a) Menor contribuição para a formação do smog, porque os gases liberados em sua combustão são menos reagentes e a formação de ozônio de baixa altitude (ozônio prejudicial) é menor;

b) Motores de combustão mais ecológicos, com menos depósitos;

c) Polui menos o ar, uma vez que não contém poluentes como o benzeno;

d) Desenvolvimento econômico rural, e;

e) Como aditivo, substitui compostos perigosos da gasolina, como o benzeno, tornando-a mais segura ambientalmente.

\section{O PIONEIRISMO BRASILEIRO: PRÓ-ÁLCOOL}

Com o novo cenário energético internacional que vem sendo criado, o Brasil se destaca por seu pioneirismo na produção de energia proveniente da biomassa, o que lhe deu completo domínio sobre a tecnologia de produção de biocombustíveis, especialmente do etanol. 
A produção brasileira se iniciou na busca de soluções para a primeira crise do petróleo em 1973, quando os países do Oriente Médio elevaram o preço do barril de petróleo de 2,90 dólares para 11,65 dólares em apenas três meses. Impulsionado tanto pela crise do petróleo como pela crise do açúcar, em 1975 criou-se o Programa Nacional do Álcool - Pró-Álcool - comandado pelo então Secretário de Tecnologia Industrial, professor José Walter Bautista Vidal, que juntamente com sua equipe começou a adaptar motores para o uso de combustível vegetal (PORTAL DO BIODIESEL, 2007).

Em 1979, tem início no Irã a Revolução Islâmica liderada pelo aiatolá Khomeini, paralisando a produção petrolífera do país. Como conseqüência tem-se a segunda crise do petróleo, elevando mais uma vez o preço do barril, que no início daquele ano era de 12,37 dólares e atingiu, em dezembro do mesmo ano, 22,77 dólares, o que, segundo Furtado, 2003 significou um aumento de $84 \%$ em menos de um ano.

Com o preço triplicado, as compras de petróleo passaram a representar $46 \%$ da pauta de importação brasileira, o que levou o governo a tomar medidas para a plena implementação do Pró-Álcool. Foram criados organismos como o Conselho Nacional do Álcool - CNAL e a Comissão Executiva Nacional do Álcool - CENAL para agilizar o programa. A produção alcooleira atingiu um pico de 12,3 bilhões de litros em 1986-87, superando em 15\% a meta inicial do governo de 10,7 bilhões de litros/ano para o fim do período (PORTAL DO BIODIESEL, 2007).

Para tornar possível tal meta, o Governo Brasileiro passou a conceder vultosos empréstimos aos grandes empresários para que estes construíssem usinas de grande porte destinadas à produção do álcool e, ainda, certas quantias, a juros subsidiados, para médios e pequenos produtores dispostos a substituir suas diversas culturas, única $\mathrm{e}$ exclusivamente, pelo cultivo da cana de açúcar.

Ainda segundo o Portal do Biodiesel, os financiamentos chegavam a cobrir até $80 \%$ do investimento fixo para destilarias à base de cana-de-açúcar e até 90\% para destilarias envolvendo outras matérias-primas, como a mandioca, sorgo sacarino, babaçu, e outros. Quanto à parte agrícola, os financiamentos chegavam até $100 \%$ do valor do orçamento, respeitando os limites de $80 \%$ e $60 \%$ do valor da produção esperada, respectivamente nas áreas da Superintendência do Desenvolvimento da Amazônia (SUDAM) e da Superintendência do Desenvolvimento do Nordeste (SUDENE).

Os investimentos governamentais não ficaram restritos apenas à produção. O Imposto de Propriedade de Veículos Automotores (IPVA) relativo aos automóveis movidos a álcool foi reduzido em até $50 \%$ em relação ao imposto cobrado aos veículos que utilizavam gasolina.

O projeto apresentou, já em curto prazo, uma série de consequiências. Entre elas, o aumento da produção de carros movidos a álcool que era de 0,46\% em 1979 e chegou a 76,1\% em 1986, além da redução no uso de gasolina, gerando um excedente de $18 \%$ que, por motivos econômicos e logísticos (uma vez que seu armazenamento requer altos investimentos), passou a ser exportada.

Os preços do barril de petróleo permaneceram altos até 1986, quando, a partir daquele ano, caíram de um patamar de 40 dólares para cerca de 12 a 20 dólares. Nesse período, 
conhecido como "contrachoque do petróleo" houve desestímulo às pesquisas em busca de combustíveis alternativos que substituíssem o uso de hidrocarbonetos fósseis em todo o mundo. No Brasil os efeitos da queda no preço do petróleo só foram sentidos a partir de 1988, quando o governo passava por um período de escassez de recursos para subsidiar programas de desenvolvimento de energias alternativas.

Com a diminuição de investimentos, a oferta do álcool não pôde acompanhar a crescente demanda provocada pela venda de carros movidos a álcool que, em 1985, representavam mais de $95 \%$ das vendas totais de automóveis.

Até meados da década de 90, vários fatores, como a súbita queda no preço do petróleo e os baixos preços pagos aos produtores de álcool, impediram o aumento da produção de etanol no Brasil. No entanto, mesmo com a oferta em crise, a demanda continuou sendo estimulada por incentivos como o baixo preço do álcool em relação à gasolina. Esse caminho inverso percorrido pela demanda em relação à oferta resultou na crise de abastecimento na entressafra de 1989-90.

Apesar de transitória, a crise de abastecimento prejudicou a credibilidade do Pró-Álcool, e juntamente com o desestímulo ao uso do combustível, provocou a diminuição nas vendas de automóveis movidos pelo mesmo, levando a quantidade de carros produzidos com motor a álcool a 1\% no final da década de 90, quando em 1982 esse percentual chegara a 90\%. De acordo com o Portal do Biodiesel, 2007, a crise de abastecimento de álcool somente foi superada com a introdução no mercado da mistura de Metanol, Etanol e Gasolina (o que se convencionou chamar de mistura MEG), que substituía, com igual desempenho, o álcool hidratado.

De 1995 a 2000 a produção e distribuição do álcool combustível encontravam-se liberadas, tendo seu preço determinado exclusivamente pelas condições do mercado. No entanto, mesmo com a estabilização e progressivo crescimento da indústria sucroalcooleira, de 1998 a 2000, a fabricação de carros movidos a álcool manteve uma média de $1 \%$.

Atualmente, o Brasil vive um período de expansão dos canaviais, que eram, tradicionalmente, cultivados apenas em áreas como o interior paulista e o Nordeste, e hoje chegam aos cerrados. Diferentemente do que aconteceu na década de 70, o interesse em construir novas usinas para aumentar a produção do etanol vem da iniciativa privada, que vê excelentes perspectivas de crescimento do mercado consumidor do etanol, e tem razões para isso. A tecnologia de motores bicombustíveis deu nova força ao consumo interno de álcool. Os automóveis com motor do tipo Flex Fuel, introduzidos no mercado brasileiro em março de 2003, têm conquistado cada vez mais consumidores e hoje, suas vendas já ultrapassam as de carros movidos à gasolina.

\section{PERSPECTIVAS PARA O ETANOL NO BRASIL E NO MUNDO}

As projeções de demanda e oferta do etanol carburante apresentam perspectivas positivas quanto ao crescimento do mercado desse combustível. De acordo com a Empresa de Pesquisa Energética - EPE - houve um aumento significativo na demanda de ácool hidratado no país, passando de $3.762 \mathrm{mil} \mathrm{m}^{3}$, em 2003 para $10.366 \mathrm{mil} \mathrm{m}^{3}$, em 2007 . 
A maior contribuição para o aquecimento do mercado de etanol foi, sem dúvida, o desenvolvimento da tecnologia de motores bicombustíveis, que deu nova força ao consumo interno de etanol. Os automóveis com motor do tipo Flex Fuel, introduzidos no mercado brasileiro em março de 2003, têm conquistado cada vez mais consumidores. Sua participação nas vendas de automóveis no mercado nacional foi de 3\% no ano de 2003, 22\% em 2004, 53\% em 2005, 82\% em 2006 e 91,3\% em 2007 (EPE - CADERNOS DE ENERGIA, 2008). E a tendência é que sua participação no mercado automotivo brasileiro continue crescendo.

Segundo estudo da EPE, entre 2008 e 2017, a participação dos automóveis Flex Fuel na frota brasileira deve aumentar cerca de $43 \%$, como mostram a tabela e o gráfico a seguir.

Tabela 1: Perfil da frota brasileira por combustível

\begin{tabular}{ccc}
\hline Discriminação & 2008 & 2017 \\
\hline Gasolina & $63,4 \%$ & $24,8 \%$ \\
Álcool & $7 \%$ & $1,6 \%$ \\
Flex-fuel & $29,6 \%$ & $73,6 \%$ \\
\hline Total & $100 \%$ & $100 \%$ \\
\hline
\end{tabular}

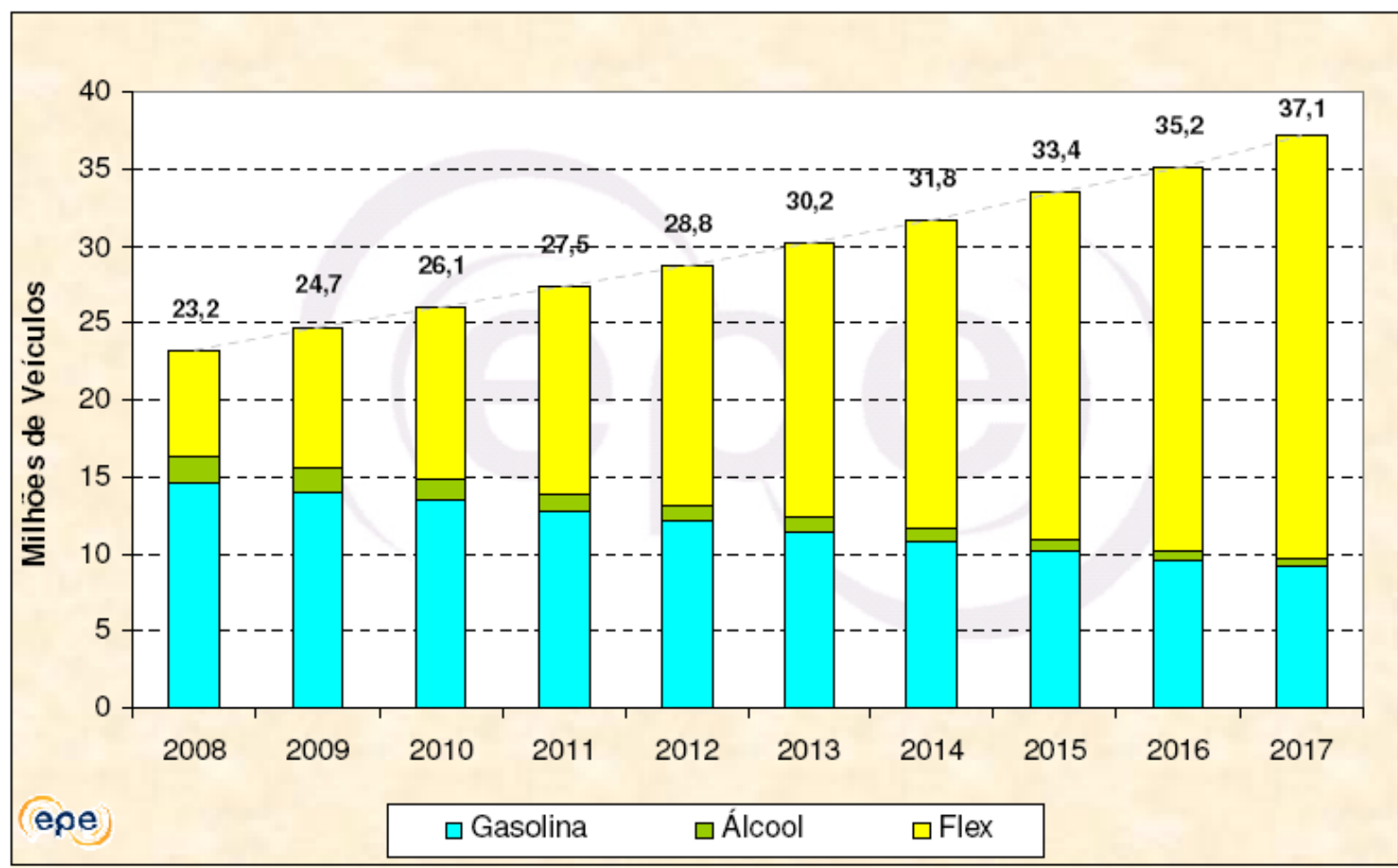

Gráfico 1 - Perfil da frota brasileira por combustível.

Entretanto, o aumento da participação dos automóveis flex fuel no mercado automotivo não é fator decisivo no aumento da demanda de etanol, se considerado isoladamente. A escolha do combustível é uma função que depende principalmente da relação entre o preço da gasolina e o preço do etanol, e, para que a demanda deste último continue crescendo, é preciso que o mesmo se apresente competitivo frente à gasolina. 
Em 2007, com a relação verificada entre os preços da gasolina e do etanol, observou-se que $75,51 \%$ da energia consumida pelos veículos leves flex fuel foram supridos por etanol. Considerando que a estrutura tributária da gasolina se mantenha a mesma, o preço da gasolina ao consumidor deve se manter acima de US\$1,47, o mesmo preço observado em 2007. Sendo assim, projeta-se que, no período entre 2008 e 2017 o etanol continue competitivo, sendo o combustível preferencial dos usuários de veículos da categoria flex fuel, mantendo sua representatividade em $75,51 \%$ da energia consumida por essa categoria (EPE - CADERNOS DE ENERGIA, 2008).

Diante dessas variáveis, espera-se que a demanda de etanol carburante cresça a uma taxa de $11,3 \%$ ao ano, conforme apresentado na Tabela 02 e no Gráfico 02.

Tabela 2: Demanda de Álcool Carburante (bilhões de litros)

\begin{tabular}{cc}
\hline Ano & Álcool Carburante \\
2008 & 20,3 \\
2009 & 24,0 \\
2010 & 27,6 \\
2011 & 31,3 \\
2012 & 35,0 \\
2013 & 38,7 \\
2014 & 42,5 \\
2015 & 46,2 \\
2016 & 49,7 \\
2017 & 53,2 \\
\hline Período & $\Delta$ \%o ano \\
\hline $2008-2012$ & 14,6 \\
$2012-2017$ & 8,7 \\
$2008-2017$ & 11,3 \\
\hline
\end{tabular}

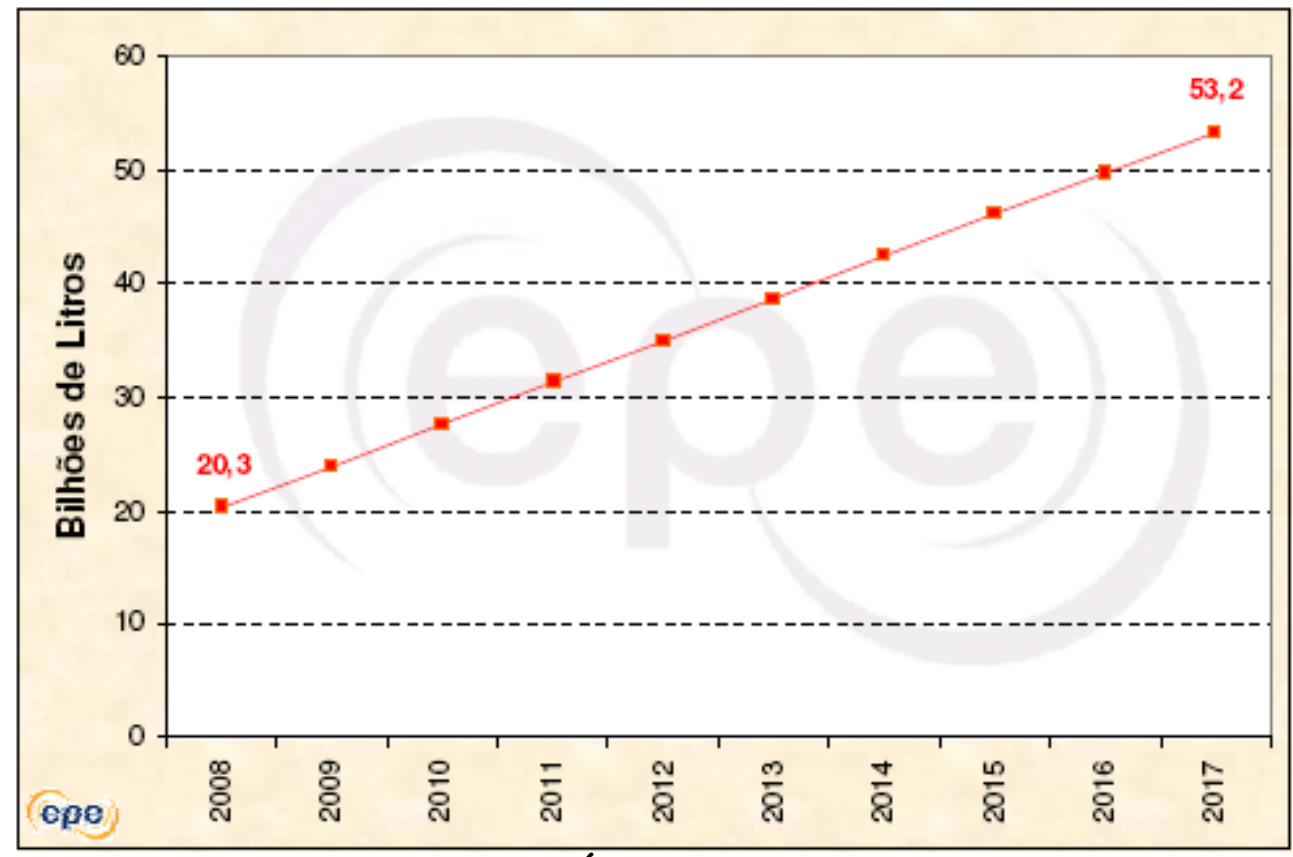

Gráfico 02 - Demanda de Álcool Carburante (bilhões de litros) 
Já o etanol para uso não carburante é utilizado no Brasil basicamente na produção de bebidas, cosméticos, produtos farmacêuticos e químicos, e este consumo, de acordo com dados do Balanço Energético Nacional apud EPE, foi de 683 milhões de litros em 2007.

Entretanto é a indústria química, em especial as fabricantes de resinas termoplásticas, as principais consumidoras do etanol não carburante. Grandes empresas produtoras de resinas termoplásticas como Dow, Solvay Indupa e Braskem anunciaram, recentemente, projetos de produção de resinas termoplásticas "verdes", oriundas do etanol (EPE - CADERNOS DE ENERGIA, 2008).

Solvay Indupa e Cooperativa de Produtores de Cana-de-Açúcar, Açúcar e Álcool do estado de São Paulo (Copersucar) assinaram contrato de 10 anos para fornecimento de etanol para produção de policloreto de vinila (PVC), a partir de 2010, com investimento na ordem de 500 milhões de dólares. Dow e Crystalserv assinaram, em junho de 2007, um Memorando de Entendimento para formação de uma joint-venture com o intuito de realizarem um estudo de viabilidade de uma unidade de produção de polietileno de baixa densidade linear (PEBDL), a iniciar suas atividades em 2011. A Braskem avalia a possibilidade de ampliar sua produção de polietileno (PE) com a construção de uma unidade com capacidade de 200 mil toneladas/ano, para início de operação a partir de 2010 (EPE - CADERNOS DE ENERGIA, 2008).

Assim, de acordo com a EPE, se os projetos forem implantados na data estimada e havendo manutenção dos patamares de produção a partir de 2011, estima-se que a demanda de etanol alcoolquímico para a produção de polímeros no Brasil será de 650 milhões de litros em 2010 e de 1,95 bilhão de litros no período compreendido entre 2011 e 2017.

\section{MERCADOS INTERNACIONAIS DE ETANOL}

Em busca da redução de emissão de gases causadores do efeito estufa, da garantia de segurança energética e do desenvolvimento da atividade agrícola, existe uma tendência de aumento do uso de biocombustíveis em vários países, e no mercado mundial de combustíveis, o etanol está sendo tratado como o combustível renovável mais viável, no curto prazo, para substituir a gasolina ou ser adicionado à mesma.

Por isso, vários países vêm desenvolvendo políticas de incentivo à produção de etanol como combustível, em especial os Estados Unidos, o Japão e os países da União Européia (EPE - CADERNOS DE ENERGIA, 2008).

\section{ESTADOS UNIDOS}

O mercado norte-americano de etanol vive um momento de expansão na demanda e na oferta do combustível. Em 2004 foram consumidos 13,5 bilhões de litros de álcool combustível, o que representou um crescimento de $23 \%$ em relação ao ano de 2003, quando o consumo foi de 10,7 bilhões de litros, e estima-se que o consumo em 2010 seja 
de 18 bilhões de litros. Já a produção passou de 6 bilhões de litros em 2000 para 12,9 bilhões de litros em 2004, um crescimento médio de 21\% ao ano (PIACENTE, 2006).

E o consumo de etanol nos Estados Unidos tende a crescer cada vez mais. Apesar de não ser signatário do Protocolo de Kyoto, o país tem grande preocupação em garantir sua segurança energética, e, com o objetivo de diminuir a dependência da gasolina como combustível, o governo norte-americano vem criando diversas leis de incentivo à indústria do etanol. Entre 2005 e 2007, segundo a EPE, 2008, destacam-se as seguintes legislações:

a) A "Energy Policy Act of 2005", EPAct 2005 - lei criada em 2005 que estabeleceu metas de consumo de combustível renovável até 2012. A lei contempla diversas ações de incentivo ao uso de etanol, entre elas a remuneração do formulador de combustíveis com US\$ 0,51 por galão de etanol adicionado à gasolina, de forma a compensar o alto custo da produção de álcool a partir do milho;

b) A “Energy Independece and Security Act of 2007”, EISA - Em janeiro de 2007, o então presidente norte-americano George W. Bush propôs uma meta de redução de utilização da gasolina em $20 \%$ nos próximos dez anos. Essa proposta ficou conhecida como Meta 20 em 10 que resultou no projeto de lei H.R.6, posteriormente convertido na lei EISA, que versa sobre combustíveis renováveis.

Como resultado dos incentivos ao uso do etanol, pode-se observar uma crescente utilização do combustível naquele país, e conseqüentemente, da produção. Segundo a Renewable Fuels Association (RFA) apud EPE 2008, a produção de etanol nos Estados Unidos apresentou um crescimento de $267 \%$ no período de 2001 a 2007, sendo produzidos 6,7 e 24,6 bilhões de litros, respectivamente. Porém, o consumo sendo superior à produção, foi complementado por importação, passando de 7,9 para 25,9 bilhões de litros no mesmo período.

Por isso, os Estados Unidos vêm aumentando seus investimentos na produção do álcool combustível. Segundo a EPE, 2008, a capacidade industrial instalada de produção de etanol era, em janeiro de 2001, de 7,3 bilhões de litros anuais, alcançando 20,8 bilhões de litros para o mesmo mês de 2007. Em maio de 2008, a capacidade norte-americana instalada chegou a 32,9 bilhões de litros que, somada à capacidade das novas usinas em construção, poderá alcançar 51,5 bilhões de litros anuais, o que deve atender a demanda interna nos próximos anos.

Apesar disso, os Estados Unidos devem continuar importando boa parte do etanol que consome. Isso porque o crescimento da produção de etanol no país, que é produzido a partir do milho, tem provocado o aumento do preço deste cereal, e conseqüentemente, dos custos de produção do combustível (EPE - CADERNOS DE ENERGIA, 2008).

\section{UNIÃO EUROPÉIA}

Motivada pelo aumento da segurança do abastecimento energético e pela redução das emissões de gases de efeito estufa, a União Européia sinalizou recentemente que a participação das fontes renováveis será de $10 \%$ da matriz energética da área de transportes 
até 2020, o que pode representar uma necessidade de aproximadamente 30 bilhões de litros de biocombustíveis em 2016 (EPE - CADERNOS DE ENERGIA, 2008).

Em 2007, a produção européia de etanol combustível chegou a 1770 milhões de litros, segundo dados do European Bioethanol Fuel Association (EBIO) apud EPE. No mesmo ano, a França alcançou a posição de líder com 578 milhões de litros anuais contra 394 milhões produzidos na Alemanha e 348 milhões na Espanha. A expansão do mercado europeu de etanol nos próximos anos deverá ser sustentada principalmente em função da produção do próprio continente, porém, como nesses países, a produção é predominantemente oriunda de beterraba, cereais e excedentes de produção de vinho, estima-se que o Brasil será seu fornecedor preferencial em virtude da alta competitividade de seu etanol.

\section{JAPÃO}

Como anfitrião da Conferência de Kyoto, e estando incluído no Anexo I do Protocolo de Kyoto, o Japão tem como meta reduzir a emissão de gases causadores do efeito estufa em 94\%, até 2012 (PIACENTE, 2006), e para isso vem buscando alternativas para diversificar sua matriz energética.

Em 2003, o governo japonês autorizou a adição de 3\% de etanol à gasolina, em caráter experimental, e atualmente, analisa a ampliação desse percentual para 10\% em 2012. Neste caso, o Japão pode se tornar um mercado potencial de aproximadamente seis bilhões de litros/ano de etanol (EPE - CADERNOS DE ENERGIA, 2008).

Diante desses argumentos, criou-se um impasse dentro do governo japonês, uma vez que, o Ministério da Fazenda daquele país, interessado em aumentar o valor agregado dos produtos, estaria defendendo o uso do ETBE, enquanto o Ministério do Meio ambiente teria optado pelo etanol (PIACENTE, 2006).

Porém, ainda existem dúvidas quanto à escolha do combustível oxigenado a ser misturado à gasolina, etanol ou $\mathrm{ETBE}^{3}$. Isso porque as poderosas indústrias petrolíferas japonesas vêm criando obstáculos para o aumento da porcentagem de etanol na mistura (etanol+gasolina). Como mostra Piacente, 2006, elas usam o argumento de que para criar uma infra-estrutura de armazenagem, transporte e distribuição do etanol, seria necessário um investimento de aproximadamente U\$ 3,5 bilhões, enquanto para a produção de ETBE, pode haver a reutilização das plantas de produção de $\mathrm{MTBE}^{4}$ desativadas em 2001, quando o mesmo foi banido do Japão. Com isso, poderão fornecer a nova mistura (gasolina + ETBE) por meio dos canais de distribuição existentes, sem a necessidade de investimentos extras.

\footnotetext{
${ }^{3}$ ETBE: Éter etil-ter-butílico - sigla em inglês de Ethyl tert-butyl ether - composto químico líquido, incolor, inflamável e volátil, resultado da síntese de etanol e isobutileno, usado como aditivo da gasolina.

${ }^{4}$ MTBE: Éter Metil Terbutílico - sigla em inglês de Methyl-Tert-Butyl-Ether - uma substância química usada na gasolina como aditivo oxigenado. É altamente solúvel em água e, portanto, difícil de recuperar o controle uma vez que tenha entrado em contato com a mesma. Por isso foi proibido em diversos países pois, armazenado em tanques subterrâneos, o MTBE pode vazar e penetrar no solo por meses ou anos, alcançando as fontes de água.
} 
Apesar das incertezas a respeito da decisão do governo japonês, segundo Piacente, 2006, dentre os principais mercados internacionais para o etanol brasileiro, considera-se o mercado japonês como o mais promissor devido aos seguintes fatores:

a) O declarado objetivo governamental de implementar a obrigatoriedade da adição do etanol à gasolina;

b) O Japão praticamente não possui capacidade de produção própria, necessitando recorrer à importação para suprir seu mercado potencial;

c) $\mathrm{O}$ forte comprometimento do Japão com as metas do Protocolo de Kyoto, que certamente exigirão uma redução considerável das emissões veiculares, e;

d) $\mathrm{O}$ interesse do governo japonês em diversificar suas fontes de energia, reduzindo o risco de desabastecimento.

E isso pode ser visto na prática. De acordo com a EPE, 2008, acordos importantes foram firmados entre a Petrobrás e empresas japonesas para a produção e exportação de etanol brasileiro, incluindo a distribuição deste no mercado japonês, além de um memorando de entendimentos entre Petrobrás e Mitsui com vistas à exportação de até três bilhões de litros de etanol por ano, durante vinte anos.

\section{DIFICULDADES PARA A CRIAÇÃO DE UM MERCADO MUNDIAL DE ETANOL}

Apesar das perspectivas positivas em relação ao aumento de demanda de etanol no mundo, a formação de um mercado consolidado para o combustível ainda é um desafio.

Para entender as dificuldades existentes na formação de um mercado mundial de etanol nos dias de hoje, é necessário se fazer um retrospecto a respeito das teorias econômicas que influenciaram e ainda influenciam as relações comerciais entre os países.

A primeira delas é o mercantilismo, desenvolvida durante o período de 1500 a 1800 por um grupo de autores europeus preocupados com o processo de construção de uma nação. Trata-se de uma doutrina altamente nacionalista, uma vez que, para os mercantilistas, uma nação deveria disciplinar suas transações internacionais a fim de promover seus próprios interesses, promovendo ao máximo suas vendas ao resto do mundo e impondo barreiras às aquisições de produtos estrangeiros, fazendo do comércio exterior um meio de acumulação de riquezas.

A doutrina mercantilista dominou as relações comerciais entre os países entre os séculos XVI e XVIII, período marcado pela consolidação de impérios e exploração sistemática de colônias. Porém, no final do século XVIII as políticas econômicas dos mercantilistas começaram a ser contestadas.

Como mostram Baumann e Gonçalves, 2004, um dos primeiros estudiosos a atacar a lógica mercantilista foi David Hume, que questionou o argumento básico de que uma economia 
poderia acumular divisas (ouro e prata) indefinidamente sem afetar com isso sua posição competitiva no mercado internacional.

De acordo com a doutrina fluxo-preço-dinheiro de Hume, uma balança comercial favorável era possível somente a curto prazo, pois a longo prazo ela seria automaticamente eliminada. Exemplificando, suponha que a Inglaterra conquistasse um saldo comercial que resultasse em um influxo de outro e prata. Em virtude de esses metais preciosos passarem a fazer parte da oferta monetária da Inglaterra, seu influxo aumentaria a quantidade de moeda em circulação. Isso conduziria a um aumento no nível de preços na Inglaterra em relação àquele de seus parceiros comerciais. Assim, os residentes na Inglaterra seriam incentivados a adquirir produtos estrangeiros, mais baratos que os produtos ingleses, e as exportações da Inglaterra cairiam, e como resultado, o saldo comercial do país seria eliminado (CARBAUGH, 2004).

Além de apresentar vantagens econômicas apenas a curto prazo, como provou Hume, a doutrina mercantilista também foi criticada por sua visão estática da economia global. Para ela, os ganhos de uma nação com o comércio surgiam à custa de seus parceiros comerciais, ou seja, em uma relação comercial entre dois países, apenas um sairia ganhando (CARBAUGH, 2004).

Então, em 1776, com a publicação de "A Riqueza das Nações", essa visão foi contestada por Adam Smith, economista clássico que defendia o livre-comércio entre as nações. Para Smith, só poderiam existir vínculos comerciais de maneira espontânea entre duas nações se ambas tivessem a ganhar com essas transações.

Utilizando a teoria do valor-trabalho, para a qual o trabalho é o único fator de produção que determina o custo para se produzir um certo bem, Smith mostrou que as diferenças de custo de produção entre as nações regulam a troca de bens entre elas, de forma que o comércio internacional se justificaria apenas quando fosse mais barato adquirir bens produzidos em outro país. Surgindo, assim, o que Smith chamou de princípio da vantagem absoluta.

Para melhor entender o argumento das vantagens absolutas, Baumann e Gonçalves, 2004, apresentam um exemplo numérico simples: em um mundo com apenas dois países e dois produtos, onde um País A produz uma unidade de alimentos utilizando 20 unidades de trabalho e uma unidade de tecidos, utilizando 10 unidades de trabalho, e um País B produz uma unidade de alimentos utilizando 10 unidades de trabalho e uma unidade de tecidos utilizando 20 unidades de trabalho; o País A tem vantagem absoluta na produção de tecidos, pois é mais barato produzir tecidos em A, enquanto o País B tem vantagem absoluta na produção de alimentos.

Nesse contexto, ambos os países se beneficiariam com o comércio entre si, pois o País A se especializaria na produção do bem que produz a um custo menor, tecidos, e importaria alimentos, que produz a um custo maior, do País B, e vice-versa.

A teoria de Smith, porém, se limita ao comércio entre nações que possuam vantagem na produção de pelo menos um bem que elas podem exportar para seu parceiro comercial, mas não se aplica a nações que sejam mais eficientes na produção de todos os bens. Por isso, como mostra Carbaugh, 2004, em 1817, David Ricardo desenvolveu um princípio para demonstrar que pode haver comércio mutuamente benéfico, mesmo quando uma das 
nações é totalmente mais eficiente na produção de todos os bens, o princípio das vantagens comparativas.

O modelo de Ricardo também supõe a existência de apenas dois países, dois produtos, e do trabalho como único fator de produção que determina o custo para se produzir um determinado bem.

Para melhor explicar a teoria Ricardiana, Carbaugh, 2004, dá o seguinte exemplo: se um País A precisa de 80 unidades de trabalho para produzir uma unidade de vinho e 90 para produzir uma unidade de tecidos, enquanto o País B utiliza 120 unidades de trabalho para produzir uma unidade de vinho e 100 para produzir uma unidade de tecidos, o País A tem vantagens absolutas na produção tanto de vinhos quanto de tecidos. Para mostrar como o intercâmbio de bens entre os países pode ser benéfico para ambos, Ricardo usa os indicadores relativos aos preços vigentes em cada país antes do comércio.

No País A, uma unidade de vinho pode ser trocada por 0,89 (80/90) unidade de tecidos, e no País B, uma unidade de vinho pode ser trocada por 1,2 (120/100) unidade de tecidos. A unidade de vinho é, portanto, relativamente mais barata no País A do que no País B, o que dá ao País A o estímulo de se especializar na produção e exportação de vinho, enquanto o País B se especializa na produção de tecidos (BAUMANN E GONÇALVES, 2004).

Dessa forma, o País B pode importar uma unidade de vinho a um custo inferior a 1,2 unidades de tecidos, e o País A pode importar mais do que 0,89 unidade de tecidos em troca de uma unidade de vinho, assim ambos os países serão beneficiados pelo comércio internacional (BAUMANN E GONÇALVES, 2004).

Desde sua formulação o conceito de vantagens comparativas tem sido um ponto de partida para a teoria de comércio internacional, e serviu como base para o desenvolvimento da teoria neoclássica.

Como mostram Baumann e Gonçalves, 2004, o modelo usado com mais freqüência no enfoque neoclássico de comércio internacional foi elaborado no início do século XX originalmente por Eli Heckscher, em 1919, e posteriormente desenvolvido por seu aluno Bertil Ohlin, no início da década de 1930.

Diferentemente das teorias clássicas, que explicavam o comércio internacional em um mundo com dois países, dois produtos e um único fator de produção, o teorema de Heckscher-Ohlin, também chamado de teoria da dotação de fatores, considera um mundo também com dois países e dois produtos, só que com dois fatores de produção determinando o custo de se produzir esses bens.

Em sua essência, essa teoria neoclássica afirma que cada país tem vantagens comparativas no produto cujo processo produtivo emprega de forma intensiva os fatores de produção abundantes naquele país. Assim, cada país produzirá e exportará o produto intensivo em seu fator abundante. 


\section{EXEMPLO DE VANTAGENS COMPARATIVAS: BRASIL X EUA}

Após discorrer as teorias que vêm norteando o comércio internacional ao longo dos séculos, é fácil identificar no mundo atual as nações que possuem vantagens na produção de etanol.

Como visto anteriormente, os principais fatores necessários para a produção de biomassa são água, terras agricultáveis e radiação solar, elementos esses que são encontrados em abundância nos países localizados nas regiões tropicais do planeta. Por sua vez, as grandes potências econômicas, que possuem clima temperado, sofrem com a ausência de radiação solar por períodos prolongados, falta de terras próprias para a agricultura e disponibilidade limitada de água.

Assim, sob a óptica do teorema de Heckscher-Ohlin, pode-se afirmar que são os países de clima tropical (em sua maioria países em desenvolvimento) que possuem vantagens comparativas na produção do álcool combustível.

Essa relação de vantagens e desvantagens comparativas entre países tropicais e temperados pode ser retratada com o exemplo dos custos de produção do etanol no Brasil e nos Estados Unidos, países de clima tropical e temperado, respectivamente. As Tabelas 04 e 05 mostram de maneira detalhada a formação dos custos para se produzir álcool combustível nesses países.

Tabela 4: Custos de produção de Etanol a partir do milho nos EUA em 2000.

\begin{tabular}{lc}
\hline & Custo por Litro - USD \\
\hline Custo Líquido da planta de origem & $\mathbf{\$ 0 , 1 3}$ \\
Custo da planta de origem (milho) & $\$ 0,23$ \\
Subsídios & $(\$ 0,11)$ \\
& \\
Custos Operacionais & $\mathbf{\$ 0 , 1 1}$ \\
Trabalhadores/Administração/Manute & $\$ 0,05$ \\
nção & $\$ 0,03$ \\
Custos Químicos & $\$ 0,04$ \\
Custos com Energia & \\
Custos de Capital & $\mathbf{\$ 0 , 0 5}$ \\
Custo Total de Produção & $\mathbf{\$ 0 , 2 9}$ \\
\hline
\end{tabular}

Nos Estados Unidos, um dos maiores produtores de etanol do mundo, o custo para se produzir um litro de álcool combustível era de aproximadamente U\$ 0.29 no ano 2000, segundo a Agência Internacional de Energia, 2004.

Isso se deve principalmente ao custo do milho, planta da qual é extraído o etanol naquele país. O cereal representa cerca de $50 \%$ dos custos totais da produção de etanol, e mesmo sendo subsidiado pelo governo, o seu custo ainda é o mais elevado entre os demais componentes que formam o custo final. 
Isso ocorre porque o milho, além de ser alimento, também é utilizado na produção de ração para animais, o que aumenta o seu preço no mercado. Já os custos operacionais, neste caso levando-se em consideração os custos com mão-de-obra, manutenção, energia consumida para produzir etanol e os custos químicos (relacionados ao processo de extração), representam cerca de um terço do custo total por litro, e o os custos de capital, cerca de um sexto do custo total por litro.

Tabela 5: Custos de produção de Etanol a partir da cana-de-açúcar no Brasil em 1990.

\begin{tabular}{lc}
\hline & Custo por Litro - USD \\
\hline Custos Operacionais & $\mathbf{\$ 0 , 1 6 7}$ \\
Trabalhadores & $\$ 0,006$ \\
Manutenção & $\$ 0,004$ \\
Custos Químicos & $\$ 0,002$ \\
Custos com Energia & $\$ 0,002$ \\
Outros & $\$ 0,004$ \\
Pagamentos de Juros sobre Capital de & $\$ 0,022$ \\
Giro & $\$ 0,127$ \\
Custos da Planta de Origem (Cana) & \\
Custos Fixos & $\mathbf{\$ 0 , 0 6 2}$ \\
Capital em 12\% taxa de depreciação & $\$ 0,051$ \\
Outros & $\$ 0,011$ \\
Custo Total de Produção & $\mathbf{\$ 0 , 2 3}$ \\
\hline
\end{tabular}

Já o Brasil é o país que tem os menores custos na produção de etanol. Por ser a maior nação tropical do mundo, detendo $12 \%$ de todos os recursos hídricos do planeta e com um potencial de 500 milhões de terras agricultáveis (dos quais apenas cerca de 10\% foram utilizados, segundo Alves Filho, 2003), o Brasil apresenta condições ímpares de desenvolvimento sustentado na agroindústria, na exploração de biodiversidade e na geração de biomassa.

Aliadas às condições geográficas e ambientais do país, estão as pesquisas e o desenvolvimento de biotecnologia, que o Brasil, ao longo dos anos, aprendeu a dominar e produzir com qualidade. Hoje, o país tem o maior projeto de energia renovável do mundo a partir da biomassa e é o único com um parque industrial de primeiro nível já instalado (ALVES FILHO, 2003).

O único detalhamento a respeito dos custos de produção etanol no Brasil, apresentado na Tabela 05, é de meados da década de 1990. Mesmo assim, os custos brasileiros daquela época são muito menores que as recentes estimativas de custo de produção de etanol nos Estados Unidos, lembrando que esses baixos custos eram obtidos sem o auxílio de subsídios por parte do Governo.

Já em estimativas mais recentes, a AIE, 2004, mostra que os custos de produção de etanol no Brasil vêm diminuindo ainda mais, chegando a $\mathrm{R} \$ 0.45$ por litro, o equivalente a U\$ 0.15 por litro em janeiro de 2004, ainda sem subsídios. 


\section{BARREIRAS COMERCIAIS}

De acordo com as teorias desenvolvidas por Smith, Ricardo, Heckscher e Ohlin, a formação de um mercado mundial de etanol deveria ter acontecido de maneira natural e simples, com os países tropicais fornecendo esse combustível para as nações de clima frio.

Estes estudiosos, porém, desenvolveram suas teorias baseados na idéia de livre-comércio um comércio livre de barreiras governamentais ao intercâmbio de mercadorias desconsiderando as barreiras comerciais já utilizadas pelos mercantilistas.

Porém, essas barreiras não deixaram de ser utilizadas pelas nações em suas relações comerciais com outros países, apenas a justificativa para o seu uso é foi mudando com o decorrer da história. A princípio, eram utilizadas pelos mercantilistas para aumentar o lucro da balança comercial do país. Com o desenvolvimento das teorias clássicas e neoclássicas, passou-se a justificar o uso de barreiras comerciais como um meio de proteção à indústria nacional, surgindo assim a teoria do protecionismo.

O protecionismo é a política comercial por meio da qual o Estado dita as políticas comerciais do país, controlando suas importações e exportações com barreiras comerciais, sejam elas tarifárias ou não, com o propósito de desenvolver o país e proteger a indústria nacional (MAIA, 2003).

Segundo Passos e Nogami, 2003, essas medidas protecionistas são aplicadas com a justificativa dos seguintes argumentos:

a) Argumento da Indústria Nascente: Uma nova indústria pode não ter condições de sobreviver à competição externa. Assim, esse argumento defende que tais indústrias deveriam ser protegidas, ao menos temporariamente, por tarifas ou cotas, até que consigam se desenvolver suficientemente para competir com empresas estrangeiras;

b) Argumento da Segurança Nacional: Dita que se deve proteger as indústrias consideradas estratégicas para a segurança nacional;

c) Argumento da Proteção ao Emprego: Deve-se promover a substituição das importações por bens fabricados pelo próprio país, estimulando, assim, a criação de novas indústrias e a geração de empregos;

d) Argumento do Combate aos Déficits Comerciais: Deve-se procurar combater saldos negativos entre importações e exportações.

e) A partir destes argumentos, os Governos criam restrições ao comércio internacional, se utilizando de barreiras:

f) Tarifárias: Restrições às importações na forma de imposto, e;

g) Não-Tarifárias: Restrições às importações não na forma de imposto, mas por outros meios, dentre os quais as quotas, os subsídios e as proibições. 


\section{O POSICIONAMENTO PROTECIONISTA DAS NAÇÕES HEGEMÔMICAS EM RELAÇÃO AO ETANOL}

Desde a Primeira Revolução Industrial, a definição da matriz energética mundial pelos combustíveis fósseis, foi fruto de forte motivação geopolítica por parte, inicialmente da Inglaterra e depois da Europa e dos Estados Unidos para que impusessem ao mundo as formas energéticas fósseis predominantes (VIDAL, 2002).

Para Vidal (2002), essa motivação foi a ausência de outras formas energéticas extensivas nas regiões temperadas e frias do planeta, onde, no hemisfério norte, se localizam as nações hegemônicas. Isso porque, as formas energéticas capazes de estabelecer um modelo energético mais consistente e limpo que o associado aos fósseis, como exposto neste trabalho, são as derivadas da biomassa que se forma nas plantas pela ação da fotossíntese solar. Elas, porém, somente são possíveis de modo extensivo nas regiões tropicais do planeta, onde sol e água são abundantes.

Mesmo após o embargo do petróleo na primeira crise ocorrida em 1973, houve grande esforço da mídia mundial, patrocinada pelas corporações petrolíferas transnacionais e pela indústria automobilística, para afastar da opinião pública a idéia de limitação das reservas de petróleo. Assim, as preocupações iniciais com a busca de alternativas ao petróleo praticamente desapareceram (VIDAL, 2002).

Essa imposição unilateral do modelo energético contemporâneo por parte das nações hegemônicas é fruto de uma política colonialista que essas nações destinam aos países menos favorecidos economicamente.

Ao longo da história essa política criou diversas desigualdades, subjugando os países em desenvolvimento às regras impostas pelas nações hegemônicas. Assim, o mundo observou uma inversão de valores em relação às riquezas oferecidas pela natureza. Enquanto os produtos industrializados, produzidos em sua maioria com menores custos pelas nações hegemônicas são permanentemente valorizados, as matérias primas e os produtos agrícolas são depreciados.

Porém, como afirma Vidal (2002), quando as vantagens comparativas são identificadas nas nações menos favorecidas, surgem nas nações hegemônicas escandalosos subsídios que impedem o justo comércio e a livre concorrência, como vem ocorrendo com os produtos agrícolas em geral e com o etanol brasileiro.

Nos Estados Unidos, por exemplo, na década de 1980, como medida temporária para incentivar o crescimento da indústria de etanol do país, foi criado um imposto para a importação de etanol que, atualmente, cobra uma tarifa de US\$ 0,1427 por cada litro de etanol importado (UNIÃO DAS INDÚSTRIAS DE CANA DE AÇÚCAR, 2009).

Para esse imposto pode haver isenção caso o produto seja oriundo de um dos 24 países que compõem o Caribbean Basin Iniciative - CBI, "Iniciativa Caribenha". Porém, é importante ressaltar que existe um limite para as importações americanas de etanol via CBI que é de $7 \%$ do volume produzido pelos EUA no ano anterior (EPE - CADERNOS DE ENERGIA, 2008). 
Além dessa tarifa, sob o argumento de estimular o uso de etanol, o Governo Americano também subsidia os distribuidores de combustível oferecendo uma remuneração de US\$ 0,12 por litro de etanol adicionado à gasolina, de forma a compensar o alto custo de produção de álcool a partir do milho.

\section{CONSIDERAÇÕES FINAIS}

Desde a Primeira Revolução Industrial, os países vêm desenvolvendo suas economias sustentados por uma matriz energética poluidora e finita. Em função disso, no final da década de 1990 e início dos anos 2000, vários países desenvolvidos e em desenvolvimentos passaram a implementar pesquisas em busca de fontes de energia capazes de suprir a demanda mundial por tempo indeterminado e que não oferecessem riscos ao meio ambiente.

O Brasil, porém, ganhou destaque nesse cenário por ter tomado a dianteira e iniciado suas pesquisas para o desenvolvimento de combustíveis limpos e renováveis, uma década antes dos demais, tornando-se, assim, referência mundial na produção dos biocombustíveis, em especial do etanol.

Atualmente, o etanol é visto como a alternativa mais barata e eficaz para substituir a gasolina, com perspectivas de aumento de demanda tanto no mercado brasileiro como no mercado internacional. Porém, o etanol ainda encontra dificuldades para se consolidar como uma commodity energética no mercado mundial, dificultando assim o aumento de sua produção e comercialização.

Isso se deve principalmente aos subsídios e aos regimes protecionistas impostos pelas nações hegemônicas que distorcem o comércio internacional do etanol, impedindo o livre fluxo deste combustível e reduzindo seu comércio a transações ocasionais.

Portanto, cabe às nações tropicais, em especial ao Brasil, o engajamento em todas as frentes de negociação possíveis, sejam elas multilaterais, regionais, bi-regionais ou bilaterais, como meio de inserção do etanol em diversos países, aumentando, gradativamente, sua comercialização no mundo, até que um mercado mundial de etanol carburante esteja consolidado.

\section{REFERÊNCIAS BIBLIOGRÁFICAS}

1. AGÊNCIA NACIONAL DE ENERGIA ELÉTRICA (Brasil). Carvão. [Brasília, 2007] Disponível em: <http://www.aneel.gov.br/aplicacoes/atlas/pdf/08Carvao(2).pdf> Acesso em 19 jul 2007.

Petróleo. Disponível em: <http://www.aneel.gov.br/aplicacoes/atlas/pdf/07Petroleo(2).pdf> Acesso em: 22 jul 2007.

2. ALVES FILHO, João. Matriz Energética Brasileira: da crise à grande esperança. Rio de Janeiro, Mauad, 2003. 
3. ETANOL. [s.l., Ambiente Brasil, 2007] Disponível em: <http://www.ambientebrasil.com.br/composer.php3?base=./energia/index.html\&conteu do=./energia/etanol.html> Acesso em: 31 mai 2007.

4. BAIRD, Colin. Química Ambiental; trad. Maria Angeles Lobo Recio e Luiz Carlos Marques Carrera, 2. ed. Porto Alegre: Bookman, 2002.

5. BAUMANN, Renato; CANUTO, Otaviano; GONÇALVES, Reinaldo. Economia Internacional: teoria e experiência brasileira. Rio de Janeiro: Elsevier, 2004.

6. CARBAUGH, Robert J. Economia internacional. São Paulo: Pioneira Thomson Learning, 2004.

7. DEPARTAMENTO DE ENERGIA ELÉTRICA DA UNIVERSIDADE ESTADUAL DE SÃO PAULO. Energia da biomassa. [s.l., s.n., 2009] Disponível em: <http://www.dee.feis.unesp.br/usinaecoeletrica/biomassa/biomassa.htm> Acesso em: 12 jun 2009.

8. EMPRESA DE PESQUISA ENERGÉTICA. Cadernos de Energia EPE : perspectivas para o etanol do Brasil [s.l., s.n.], 2008. Disponível em: <http://www.epe.gov.br/Petroleo/Documents/Estudos_28/Cadernos\%20de\%20Energia $\% 20-\% 20$ Perspectiva\%20para\%20o\%20etanol\%20no\%20Brasil.pdf> Acesso em: 12 fev 2009.

9. FACULDADE DE CIÊNCIAS E TECNOLOGIA DA UNIVERSIDADE DE COIMBRA. Estudo de Caso: produção de etanol. Coimbra, [2007] Disponível em: <http://www.eq.uc.pt/ ines/seminario/ciappq08.html> Acesso em 31 mai 2207.

10. FURTADO, Milton Braga. Síntese da Economia Brasileira, 7. ed., Rio de Janeiro, Livros Técnicos e Científicos Editora, 2003.

11. HINRICHS, Roger A., KLEINBACH, Merlin. Energia e meio ambiente. São Paulo, Pioneira Thomson Learning, 2003.

12. INSTITUTO SOCIOAMBIENTAL (Brasil). O uso de um bem coletivo para fins privados. Disponível em <http://www.socioambiental.org/inst/camp/Ribeira/energia> Acesso em: 20 jul 2007.

13. LUZ, Rodrigo Teixeira. Relações Econômicas Internacionais: teoria e questões. Rio de Janeiro: Elsevier, 2006.

14. MILARÉ, Edis. Direito do Ambiente: doutrina, jurisprudência, glossário. 4. ed. São Paulo: Editora Revista dos Tribunais, 2005.

15. NOGAMI, Otto; PASSOS, Carlos Roberto Martins. Princípios da Economia. - 4. ed. São Paulo: Pioneira Thomson Learning, 2003.

16. PIACENTE, Erik Augusto. Perspectivas do Brasil no Mercado Internacional de Etanol. Dissertação de mestrado. Universidade Estadual de Campinas, 2006.

17. VANTAGENS do biodiesel. [s.1., Portal BiodeieselBR, 2009] Disponível em: $<$ http://www.biodieselbr.com/biodiesel/vantagens/vantagens-biodiesel.htm> Acesso em: 05 mai 2009.

18. PRÓ-ÁLCOOL: Programa Brasileiro de Álcool. [s.1., Portal do Biodiesel, 2007] Disponível em: <http://www.biodieselbr.com/proalcool/pro-alcool.htm> Acesso em: 15 jun 2007. 
19. CARTILHA do etanol. [s.1., Portal Etanol Verde, 2009] Disponível em: <http://www.etanolverde.com.br/telas/cartilha/default.aspx> Acesso em: 14 mai 2009.

20. ENTENDA o protocolo de Kyoto. Revista Época, Edição 352, 14 fev 2005, Disponível em: <http://revistaepoca.globo.com/Epoca/0,6993,EPT908417-16551,00.html> Acesso em: 18 mai 2007.

21. TERRA azul. O aquecimento global. Disponível em <http://www.terrazul.m2014.net/spip.php?article231> Acesso em 16 mai 2007.

22. UNIÃO DA INDÚSTRIA DE CANA-DE-AÇÚCAR. Novo projeto de lei considera tarifa americana sobre importação de etanol. Disponível em: <http://www.unica.com.br/noticias/show.asp?nwsCode=18969E3F-EAFA-49A3B1BB7089715D7936> Acesso em: 22 jul 2009

23. VERGARA, Sylvia Constant. Projetos e relatórios de pesquisa em administração. 9 e.d. São Paulo: Atlas, 2007.

24. VIDAL, José Bautista.[s.1., s.n., 2008] Posicionamento do Brasil Frente ao Novo Ambiente Mundial. Disponível em: <http://www.bndes.gov.br/conhecimento/seminario/alcool_discussao1.pdf> Acesso em: 19 set 2008. 